\title{
NATIONHOOD AND THE QUEST FOR NATIONAL DEVELOPMENT: THE GAMBIA'S EXPERIENCE UNDER THE SECOND REPUBLIC, 1994 - 2015
}

\author{
Oyejide Felix Omotosho ${ }^{1^{*}}$; Derin K. Ologbenla ${ }^{2}$; Akpotu H. Ezire ${ }^{3}$ \\ ${ }^{1}$ Dr. Political Science Department, The University of the Gambia, Brikama, THE GAMBIA, \\ ofomotosho@utg.edu.gm, fomotosho1967@yahoo.com \\ ${ }^{2}$ Prof. Political Science Department, University of Lagos, Akoka, Yaba, Lagos, NIGERIA, \\ dologbenla@unilag.edu.ng, derin ologbenla@yahoo.com \\ ${ }^{3}$ High Commission of the Federal Republic of Nigeria, THE GAMBIA, henryspeaks@yahoo.com, \\ harryezire@yahoo.com \\ ${ }^{*}$ Corresponding Author
}

\begin{abstract}
The task of nation-building today in the world is that which carries along all well-meaning modern nationstates, with Gambia as no exemption. This paper examines the nationhood process and effort in the Gambia between 1994 and 2015. It focuses on national development efforts both in the first and second republics. The paper investigates how human, material and ecological resources are harnessed and deployed towards this noble goal, availing enabling policy-thrusts for effective implementation and goal attainments that attract sustainable socio-economic and political development. The paper beams searchlights on the redoubled efforts under the Yahya Jammeh regime and the pragmatic approaches taken to achieve more meaningfully goal-oriented national development strides that pave ways for practical development giants and strides. An inductive and deductive methods of research that are descriptive and fact-finding are employed for empirical and critical explorations. The paper posits that the strategies of the second republic government, which surpass the first republic's conservatively-constructed approaches under Jawara served as impetus for the accomplishments recorded from 1994 to 2015 in making the Gambia an economic super power through industrialization of the agro-economic structures and processes of the small nation in the sub-Saharan Africa.
\end{abstract}

Keywords: Nation, Nationhood, National Development, The Gambia, Second Republic, Independence.

\section{INTRODUCTION}

\subsection{BACKGROUND TO STUDY:}

In this study, the meanings to the concepts of 'Nation' and 'Nationhood' are searched with conceptual approaches, given the considerations of such an effort into how nations or nation-states, as the case may be, strive for national development, in meeting with state objectives and directional goals, under a vibrant, pragmatic and people-oriented political leadership. An inference is drawn into the Gambia's experience by surveying happenings beginning from 1994 when the country attained independence and how the efforts have been re-doubled through pragmatic approaches and political determinism with the inception of the second republic in 1994 under Yahya Jammeh. Consequent upon this, the strategies and approaches that the Jammeh administration has put in place in the formulation, execution and realization of policies and plans for his visionary objectives are explored so as to decipher the basic inductive and deductive facts for objective analysis and generalized conclusions. 


\section{CONCEPTUALIZING NATION AND NATIONHOOD WITH METHODOLOGICAL AND EMPIRICAL APPROACHES}

The term nation has not been easy to define with precision. As a result, academics and the statesmen who have attempted this effort to defining the concept have had to grapple with some complications and contestations that have called for a consensus on what exactly it is? The term, having associated with itself both a political meaning, ethno-cultural and ethnographic conceptions, is believed to be natural-inclined in the one part and politically motivated in the other part.

A great political and law historian, Ernst Renan, writing in 1882 on 'What is a Nation'? views it as a soul and spiritual principle, saying it is a two-in-one concept, with one in the past and the other in the present. The one in the past is the possession in common of a rich legacy of memories; the other is present - day consent, the desire to live together, the will to perpetuate the value of the heritage that one has received in an undivided form (http://www.google.com/search?q=\%22Qu\%27es++nation\&tbs=bks\%3Al\&tbo=) He describes a nation as 'a daily referendum', saying nations are based on what the people jointly forget and what they jointly remember with semantic reference to nationalism and national identity. This corroborates Omotosho's view of nationhood as the citizenry's efforts under an organized government to realize national objectives and goals. Renan begins his essay by noting that there is frequent confusion between the idea of nationhood and of racial or linguistic groupings, that which has produced the gravest errors (Renan, 2011, Omotosho, 2015). To Renan, the essence of a nation is that the people have many things in common, but have also forgotten much together and to him, this is what forms nationhood. While many nations, like France begin with a feudal regime such as a monarchy, others, such as the United States and Switzerland are formed by acts of consensual aggregation. He ruled out race, language and religion as being the deep-seated roots for a nation, citing the case of France, Germany, England, Spain, Italy and Switzerland as unique in the making of nations as modern countries, much as people think otherwise (Renan: 2011). A very important element of nationhood, says Renan, is the desire to continue forming part of the nation, just as the continuing existence of an individual is a perpetual affirmation of life. Renan concludes that nationhood is not an eternal concept, but changes over time the way everything in the world changes (Renan: 2011).

Another political historian, Karl Deutsh, in a quote sometimes mistakenly attributed to Renan, has said that a nation is "a group of people united by a mistaken view about the past and a hatred of their neighbors" (Renan, 2011 and Gettel, 1933). For Anderson in his 1983 work 'Imagined political community' refuting Renan's claim when the latter says French people must have forgotten the St. Bartholomew's Day massacre when Renan was trying to draw analogy between the past and the present with 'French' as a variable. The condemnation of Anderson was on the grounds of his own thought about the French state on how the French of Renan's time took no notice of this past because such were not practically brought to their memories as they learnt of them in state-run schools, hence a deliberate attempt by the state to write-off the past (Renan, 2011).

A distinguished political scientist, Dankwart Rustov in Anifowoshe et al., alerts us to the subjective and objective dimensions of nationhood. On the subjective side are feelings of attitudes and symbols that lead a people to their own national identification which breeds nationalism and sense of belonging. On the objective side are factors like history, common territory, language or literature, culture and traits. Hence, while not all the objective traits are really needed to make a nation or nation-state substantial portion of them together with the larger aspects of the subjective ideals is what instigate the formation of a nation to a full nation-state (Maclver, 1962: 22; Anifowoshe, et al., 2005: 91-92; Barker, 1961). Therefore, to these scholars, a modern nation or state is conceived from this perception as a body of people, occupying a territorial society, who possess a formal organization of public authority for controlling their behavior. This authority is the only one recognized by all members of the association and is not subordinate to any other government. This in itself begins nationhood and the quest for national consciousness, growth and development to protect national sovereignty and interest (Anifowoshe, 2005:91). This then suggests as posited by(Nnaocha, 2012:1) on this contested phenomenon, referring to it originally, 'as the genuine and determined efforts of newlyindependent nations, notably the nations of Africa, to reshape colonial territories that have been carved out by colonial powers without regard to ethnic or other boundaries', the Gambia inclusive. Asserting further on this elusive concept, Nnaocha says...'nation-state refers to the process of constructing/structuring a national identity using the power of the state and or the peoples, a process that aims at the unification of the peoples(ethnic groups) within a defined territory so that it remains a political entity and viable in the long run'. To him, the growth and development of any nation actually depends largely on the structures that the colonialists have carved out for themselves and to some extent what they the nationalists have agitated by themselves (Nnaocha, 2012:2). 
In punctuating their own concept of a nation as 'State', (Garner, et al., 2012: 27=29), view it as a notoriously difficult concept to define as it is a classic example of an essentially contested term (Gallie, 1955-6). In Garner's words, 'Some have argued that the state is not a suitable concept for political theory, since it is impossible to define it just as (Hoffman and Graham, 2006:22) have concurred'. Garner, et al., 2012:27 eventually conceive of a state (nation or nation-state) as one which seeks an institutional control of both physical, human and other materials in autonomy from other states with full legitimacy and recognition by other states of such state control and existence, thereby, corroborating the perceptions of Weber, William Blackstone and Jean Bodin (1529 - 96), the latter (Bodin) being the one who happened to have developed the concept of a sovereign state. To him and Blackstone, the idea of the sovereign state denotes its superiority as the highest form of authority in a particular territory which no other one supersedes within the territory, but, which is confronted with some external quagmires and challenges like the roles and activities of the institutional regimes that are increasingly becoming more formidable and unprecedented (Laski, 1967, Barker, 1928 and 1961, Heywood, 2007:110-126 and Appadorai, 1975:14-18).

For Roskin, et al., (1994: 26-34), in their own submission, the term nation has also been around for centuries, but not necessarily in its present sense. Far back in history, as they maintain, human groups called themselves nations, but originally this meant something like a big tribe, such as the "nation of Israel" or "Sioux nation". The Latin root of nation means 'birth' connoting where you were born into and had some blood linkage with. The term ethnic group, from the Greek ethos "nation", in turn is from the Greek for custom, ethos, indicating people with shared customs. In the seventeenth century, this nomenclature and status changed dramatically to mean large, powerful political entities that currently govern their territories and their people. State power was merged with the notion of a people with much in common (history, culture, language) occupying a territory which transformed to a nation-state, a combination of people (nation) and government structure (state), which is simply referred as nation. The rise of the modern nations, prompted by history of nationalism and feeling of nationhood which was begun in Europe during the Renaissance age, culminating into the defeat of the papacy hegemony and the concomitant fall of the Roman Empire witnessed a surge in the rise of newer and mostly smaller states in Europe apart from Russia, Greece, Sparta and the likes. This development facilitated the agreement reached by the European states to close deals on 'Monarchs' rules and settled for state system and genuine World Order, transforming into the Westphalia Treaty of 1648, the same era that heralded the emergence of international regime by the World Oligopolies (Holsti, K.J. 1983:29-92, Akinboye and Ottoh, 2005:83-110). As remarked by Garner, et al. (2012: 120-121), 'It is undoubtedly the case that the desire to organize political communities according to nationalistic principles has been of central importance in the past two centuries. Nationalism emerged in the $19^{\text {th }}$ century, as the decline of monarchical power and authority eroded previous loyalties' (Garner, et al, 2012: 121-122, Hoffman and Graham, 2006: 266). The search for national identity was initially a European phenomenon, centering on the striving for German and Italian unification, achieved in 1871 and 1861 respectively and, after the end of the First World War, national self-determination as set out by the then US President, Woodrow Wilson in the peace settlement. After the Second World War, this wind of nationalism shifted base and direction to the colonial territories of Africa, Asia and some parts of the Persian Gulf where the European colonizers were still in firm control of their colonies and where the indigenous settlers and colonial subjects had been awakened to self-consciousness and determination, following UN's declaration on this and increased level of the world's globalization with mutual respect for sovereignty of nations, irrespective of size, economy and military strength. This tempo increased the number of sovereign nations in the globe within the juridical influence of the UN system that took the stage to harmonize international actors' behaviors and actions for world peace and security (Garner, et al, 2012; Hoffman and Graham, 2006; Gareis, 2012 and you can also see the web link www.oxfordtextbooks.co.uk/orc/garner/ze).

Roskin, et al, 1994: 28-34 list as elements of nationhood the following namely; territory, population, independence and government, corroborating the generally accepted consensus elements of territory, population, government, permanence and membership of the United Nations as a sovereign national unit by scholars of 'Nations and Nationalism'. Roskin e tal, do not, of course, hold back on the challenging factors to nationhood, which include problem with identity, legitimacy, penetration, participation, resource distribution, war and other crises, by identifying them for possible survey-analysis and a proof that, nation becomes nation-state not from the sky, but, from the struggles of human, material and ecological forces that prepare it to manifest towards nationhood (Heywood, 2007:110, Appadorai, 1975:14).

The extensions of these struggles which came as nationalist movements in the colonial territories of the subSaharan Africa in the 1960s blew across the land of the place now called The Gambia, during which her nationhood was developed in 1965 when it got her independence from Britain on February 18. The resultant effect was the quest for national development, through cooperation and diplomacy with the outside world and through internal efforts made by the political gladiators and actors in building a virile and self-reliant nation. 
We can therefore view national development as that effort coordinated by a sovereign state through its agency (government) to commit all its citizenry and other physical, material and immaterial resources to genuine intents and strives towards nation-building through capacity utilization and empowerment. This, The Gambia has been part within the global continuum and the New World Order in the post-cold war era. National development is a conceivable effort of statecraft by all stakeholders, usually planned in phases or facets for targeted sustainable growth rates that are susceptible to change and measurement/ assessment under a dynamic and people-centric government. This mechanism usually follows a process that involves planned strategies with a great vision for future growth and self-sustenance that will avoid any form of overreliance of a nation on others without recourse. Such development strives engage the tools of expertise, economic drivers inherent in an economy as well as a stable political environment and viable electoral process that guarantee enormous peace for attainable self-sustaining development, believed to make a nation giant (Omotosho, 2014).

\section{SUSTAINABLE NATIONAL DEVELOPMENT AND STRIDES: THE GAMBIA'S SECOND REPUBLIC IN FOCUS}

The Gambia is a small country on the West Coast of Africa. It is fondly referred to as the Gateway and Smiling Coast of West Africa because of its strategic location on the Atlantic Ocean to the rest of the world. It extends inland for about $400 \mathrm{~km}$ along the banks of the river Gambia at widths varying from 24 to $28 \mathrm{~km}$, covering an approximate land area of $11,000 \mathrm{sq} \mathrm{km}$. It is bordered on the North, South and East by the Republic of Senegal and on the West by the Atlantic Ocean, with a population of about 1.8million. Source (2013 census release), growing at a rate of over $4.1 \%$ per annum, The Gambia is a multi-ethnic and a multiracial society with an unparalleled degree of ethnic, racial and religious tolerance and civil tranquility. Small as it is, it has over fifteen ethnic groupings, with Mandinka being $36 \%$ as the largest, Fula $22 \%$, Wollof $14 \%$, Jola $11 \%$ alongside other smaller units like the Serre, the Bambara, Majango, Aku (the ex-slaves) who were left at the Gambia's coast after slave trade or later returned to the Gambia before independence, among others. The Gambia is an overwhelming Islamic state but by its 1996 constitution, recognized as a secular state to give room for free faiths as portions of the population are mainly Catholics and other Christian folks like Methodist, Baptist and the Pentecostals, while the insignificant remaining population are animists. Originally, it was part of Mali Empire, later the ancient Ghana and finally the Songhai Empires before becoming a geo-political entity as a nation. The country is divided into seven administrative regions of West, North-Bank, Lower-River, Central-River and Upper-River with two Municipalities of Kanifing and Banjul. Its capital city is Banjul formerly Barthust(which clocks 200years, this April) as one of the oldest in the subSaharan Africa. Politically, it is divided into eight local government areas (LGAs), 35 Districts, 114 Wards and 2070 village Development Councils for administrative convenience and development-oriented economic planning. Its political system is unitary- presidential, with a supreme constitution and a popularly elected President of the republic. It has a fascinating electoral regime and behavior, with a multi-party politics of First-Past-the-Post system with the use of "Drums and Marbles" voting system to cater for the shortfall in the literacy level of the polity (Omotosho, 2014, 2015 and 2016, Hughes and Perfect, 2006, Perfect, 2008, Jagne, 2015 and Faal, 2008 and see the link; http://www.statehouse.gm/vision2020/conlusion.htm).

One significant effort first made towards national development was the independence attainment, coupled with the refusal of the Sir Jawara regime in the first republic to sign an accord of stay with the sister republic of Senegal as 'Sene-Gambia'. That move made by the colonialists on the intent to take future advantage of the development within the territory, and which was rebuffed by Jawara regime was a remarkable decision to give the small nation a sound footing for good take-off. Jawara was quick to say and decide that The Gambia was viable and stable enough to grow and sustain as a sovereign nation, a development appreciated by the vast majority of the Gambian population (Faal, 2008). In addition, the first government was able to consolidate on the unity and natural peace that exist within the atmospheric regions of the state, where Wollof as a language is widely spoken in the country up to neighboring Senegal and where people are united as a people, despite other political and artificially created features that tended to set them apart and despite, that the Wollof are not the dominant ethnic group in the state. This created a robust atmosphere and an enabling environment for nation-building (Omotosho, 2014). With peace, development is unlimited, the saying goes.

In the first ten years after independence, macro-economic conditions in The Gambia were broadly stable and economic growth rates impressive, averaging $6-7 \%$ per annum in real terms. However, from $1975-1985$, the year of world crisis, the performance of the economic state weakened considerably. During this decade, the economy was confronted with numerous imbalances on both the domestic and external fronts culminating in economic crises in the 1980s. To redress these imbalances, a strategic state policy was induced as Economy Recovery Programme (ERP) embarked upon in the mid-1985 with assistance from the 
World Bank, the International Monetary Fund and other multilateral and bilateral donors. The ERP under President Jawara succeeded partly in stabilizing the economy but failed to achieve the ultimate objective of ensuring sustainable growth. This prompted its being replaced by the Program for Sustainable Development (PSD) in 1988/89 when ERP expired http://dailynews.gmafrica/gambia/article/an-in-depth-analysis-ofdevelopment-registered-before-22july-and-after-asgambia-celebrates-48thhttp://www.statehouse.gm/vision2020/conlusion.htm. Suffices to say, that, since 1985, The Gambia made considerable progress in economic management, however, per capita income barely increased during this period (partly, as a result of rapid demographic growth), lagging behind high and middle income countries in terms of social indices. The production base on economic remains narrow and national income still depends heavily on volatile activities like tourism, re-export trade and an undiversified agricultural system with very little, if no industrial activity (http://dailynews.gmafrica/gambia/article/an-in-depth-analysis-of-developmentregistered-before-22july-and-after-asgambia-celebrates-48th-

http://www.statehouse.gm/vision2020/conlusion.htm, http://eeas.europa.eu/delegations/gambia/eu/gambiadevelpomentcooperation/index.en.htm.

In the first republic, where, we experienced this low level of economic performance and political will to strategically position the economy for a greater performance, things were worsened by the astronomical level of corruption in the polity, an occurrence that was inimical for any promising viability. The conservativeled Jawara administration condoned indiscipline and ostentations among his cabinet officials without checks on their atrocities. This increased the rate of unemployment, debt profile and decaying infrastructures that became unkempt, as state resources were wrongly diverted without trace.

Inflation increased considerably as education was given a leap attention in encouraging people to go to school for broadened and deepened analytical minds. The Gambia was in this saga/scenario till 1994 when a revolution took place and brought an era of a new republic under Yahya Jammeh. The new government settled down and set out objectives for strategic plans that heralded "The Gambia's incorporated...Vision 2020", a Vision coordinated by national think-tank and a Blueprint meant to transform the small nation into a palace golden fleece for a global economic hub. In consequence, six major activity areas were brought to focus under the agenda for achievements and they were Agriculture, Industry, Trade, Tourism, Finance and Banking and Manpower Development and Innovation. This was structured around the following broad parts, namely;

Part 1- bringing to light the objectives of the Mission statement in more concrete terms so as to give a better feel of the height of the noble objective in a document form, known as "The Vision Document",

\section{Part 2-diagnosing the present situation as measurement of the Vision's aspiration level and}

Part 3-highlighting in concrete terms the strategies with which the state is to effectively and efficiently pursue and achieve the stated goals and objectives.

In achieving this noble objective, the government made wide consultations and popular outreach with the people in order to carry everybody along and make everyone to contribute massively to national development efforts under the new regime. Such wide consultations did not only create awareness among the populace, but sensitized them towards the importance of nation-building and the alacrity to rally round the new administration for home support and material and psychological backing. The consultations, which went with seminars and community talks on the Vision, helped also to eradicate ignorance, conservatism and illiteracy among the larger society up to the rural settlements in the provinces, creating a high level of awareness and consciousness to self-reliance and hard work. Based on this, the new government became very popular among the citizenry as all and sundry are carried along and are given opportunities to tap potentials through available economic drivers, mainly, education, agriculture, business and tourism. It was on this premise that broad outline of policies to facilitate objective realization and full accomplishment that the transformational agenda to be spread over a period of twenty five years were visualized and scientifically conceptualized (http://www.statehouse.gm/vision2020/conclusion.htm). In this popular participation, it was held that the Gambia had a number of weaknesses and internal imbalances that needed to be addressed, just as it was also acknowledged that there present some potentials and values that give her strengths for a vibrant economic performance and strides. Such strengths were identified as the natural peace the country is blessed with, which is a development indicator for investment flows and export earnings, while others were the arable lands the country possesses to expand agriculture and diversify the economy from its trado-tourist indices for surplus food and exports. Weaknesses like corruption in the public service, maintenance culture, illiteracy, poverty, starvation, early marriages of girls and their withdrawals by their parents from schools for economic reasons and unemployment to mention just a few were named as germane to underdevelopment and serious backwardness (Omotosho, 2015). Agriculture was identified as the country's mainstay and if 
dependence and poverty would be defeated, people must be oriented towards farming to produce more food, of course, in surplus and for exports to boost gross national income, while increasing gross domestic income through tax generation in a robust employable economy for capacity building. In effect, a strategic policy of "Let's Grow What We Eat and Eat What We Grow" was embraced through institutional framework and thrust. Today, the country is billed to be exporting rice as one of its crops for foreign reserves. On education, not only was the Girl-Child Education Program launched but stupendous number of schools are built nationwide in collaboration with several intergovernmental and non-governmental organizations and agencies like the UN, the European Union and some other richer nations of the world, both within and outside the region, like Nigeria, Venezuela, Cuba, Qatar, America, Britain and the Kingdom of Saudi Arabia. These countries and agencies entered into agreements with the government of the Gambia to expand infrastructures, boost growth rates, establish industries, build schools, improve on the health sector, agronomy and generate appreciable income and employment on mutual ground of respect for the sovereignty of the small nation, The university of the Gambia and other higher institutions were built in 1999 to produce the needed manpower for the nation and boost research and development through the nation's ivory tower. The Jammeh Foundation for Peace was envisioned to support the downtrodden and the underprivileged and this gave birth to Jammeh Hospital and the Trado-medical care for the treatments of chronic ailments like Aids/Virus, infertility, tuberculosis, paralysis, blindness the list goes on. In agriculture, fisheries were improved on as it constitutes a greater percentage of income and employment generation for the rural populace in order to boost production and so the business sector was not left behind, with the banking and finance industry in the lead to encourage capital retention and finance, whereby, money can be available to borrow and encourage the growths of small and middle- scale businesses and enterprises for the Gambians. This has proven successful and rewarding in fast-tracking sustainable development nationally. For the tourist industry, enormous foreign investments were attracted from the outside through the economic diplomacy of the Jammeh administration to boost local earnings and foreign reserves. This generated a lot of employment for the youths in particular while encouraging urbanization. The entertainment industry and sports are not left behind in this crusade, as the government pumped in some money to boost expansion for income generation and youth engagement in national growth. The women were empowered economically and politically for them to be fully engaged and utilized in the national interest, while balancing gender inequalities in the society. To this end, several projects were launched like National Youth Council, The Women Bureau etc. to boost participation and empowerment.

Among those laudable programs put in place by the administration was the Millennium Development Goal (MDGs) for 1916, believed to have been assessed by the sponsors like the United Nations Development Program (UNDP), as very successful and achieving, This program, aimed at eradicating poverty, illiteracy and unemployment, while creating catalysts for food security, youth employability, women empowerment, robust infrastructural growth and expansion, especially in the transport section, health(which is wealth), education and skills acquisition. http://www.ruralpovertyportal.org/country/approaches/tags/gambia

\section{RURAL POVERTY ALLEVIATION AND STRATEGIES IN THE SECOND REPUBLIC GAMBIA}

Since the mid-1980s, The Gambia has implemented economic policies favouring macroeconomic stability, market liberalization and private-sector development. In the 1990s, the government adopted a long-term strategy, The Gambia incorporated vision 2020, as a blueprint for accelerated and sustainable development to turn The Gambia into a middle-income country.

More recently, The Gambia's framework for poverty reduction, food security and growth was outlined in its Programme for Accelerated Growth and Employment 2012-2015 (PAGE) (the successor document to previous poverty reduction strategy papers). The program builds upon the Millennium Development Goals (MDGs) and the objectives of Vision 2020 and defines the overall government strategy for achieving sustainable growth and development. It recognizes that poverty reduction in rural areas requires priority investment in the agriculture, health and education sectors.

Another key document, the Agricultural and Natural Resources Policy (ANRP) 2009-2015, was approved and launched at The Gambia's first-ever national farmers' conference. This policy is part of the government's commitment to transforming agriculture into a robust, market-oriented sector that makes an important contribution to poverty reduction and economic growth - and to meeting the country's MDGs.

The four strategic objectives that ANRP sets out for 2015 are:

- Improved and sustainable levels of food and nutrition security throughout the country, particularly among vulnerable populations. 
- A commercialized agricultural sector, ensuring competitive, efficient value chains and market linkages.

- Stronger public and private institutions to provide services and help reduce vulnerability to food and nutrition insecurity.
Sustainable
and
effective
management
of
natural
resources.

The country's most important blueprint for agricultural development is The Gambia National Agricultural Investment Programme (GNAIP) 2011-2015. Fully aligned with the goals of Vision 2020, the plan guides propoor investments. As the main pathway to sustainable development, it looks towards changing the orientation of the agricultural and natural resource sector from subsistence to commercial production, with a focus on smallholders. GNAIP thus serves as a basis for all donors in the sector to match their future interventions with government plans and priorities.

The estimated investment required to achieve full implementation of GNAIP is more than US\$200 million for the programme's six main components:

- Improvement of agricultural land and water management.

- Improved management of other shared resources.

- Development of agricultural value chains and market promotion.

- National food and nutrition security.

- Sustainable farm development.

- GNAIP coordination, monitoring and evaluation. (http://www.ruralpovertyportal.org/country/approa ches/tags/gambia)

The Government of The Gambia has also made strides in developing other sectoral policies - particularly the Gender and Women Empowerment Policy 2010-2020 and National Youth Policy 2009 - 2018. In future years, the full implementation of these policies will complement the country's broader socio-economic growth and sustainable development.

Although The Gambia is a party to the Maputo Declaration, which obliges governments to allocate at least 10 per cent of their annual national budgets to agriculture, its annual budget allocation to the agriculture sector is around 7 per cent. However, the government is adopting a public-private partnership approach to fill critical investment and service gaps in the agriculture and rural development sectors. The private sector is expected to assume a lead role in providing enterprise investment resources and entrepreneurial management, while the public sector serves as a facilitator and catalyst. Public-private investments in the production and expansion of field crops, and in livestock and horticulture, will be especially advantageous.

Source: http://www.ruralpovertyportal.org/country/approaches/tags/gambia This project was powered by International Fund for Agricultural Development (IFAD), The Gambia, 2012-2016.

On the political front, corruption and crimes were confronted head on, using institutional frameworks like War Against Indiscipline, Environmental sanitation locally called Cellcetta, National Drug law Enforcement Agency, Rumor Spreading and Gossiping, for them to tackle corruption and fight crimes in the overall interest of a harmonious and crime-free society where businesses and opportunities can thrive for national unity and growth. These attracted enormous foreign investment flows and instilled discipline in the citizens, making them responsive and ever-more useful as dependable workforce, especially in the public service. This promoted good governance and disciplined workforce as well as positive and progressive thinking society. Religious tolerance is accommodated and public fighting prohibited discouraging any form of hooliganism and gangsterism in public places, especially, those common among the youths at club houses, bus stops and garages, where the unemployed do gather to foment trouble for desperate politicians and illgotten business moguls for just a tip.

\section{CONCLUSION/RECOMMENDATIONS}

With the United Nations Development Assistance Framework in partnership with the government of the Gambia for effective monitoring mechanism, 2012-2016 as well as the effective implementation mechanism of National Development Strategy 2020 of Warsaw Pact, September, 2012, the government of the Gambia has been able, not only to lay a good foundation for a good economic take-off for a sustainable economy in 
the $21^{\text {st }}$ century. As at 2015 , the government has been able to vigorously pursue and commended for its accelerated objectives that are believed to have yielded positive results for true nation-building process. Although, much still need to be done in tackling indiscipline in society and fighting corruption (the enemy of development), in order to realize total war against these menace, the reason for which the government should step up more efforts to eliminating them and build confidence in foreign and local investors. An institutional mechanism is required to engaging investors for robust investments through favorable tax regime that will favor both the state and the future investors, especially in an increasingly volatile world economy that is frustrating cash flows, favorable international trade and technology transfer. Aside, more efforts are still required to encourage local technology by promoting science and technical education and skills acquisition among the growing youths, who are leaders of tomorrow and engine of development. More is also still needed to promoting harmony and love among the diverse populace by shunning all forms of tribalism, ethno-centric feelings and hate which sometimes occur, especially during national and ethnic events within the polity. More is needed to garner more support and political patronage for the government in order to boost the latter's ego and enthusiasm towards national efforts and integration. This will spur the government into pragmatic steps that will actually and genuinely achieve for the nation the blueprint document on the Vision 2025 and the dream of an economic super- power that the government is prepared to achieve for the country by 2025 and after. In this sense, a collective approach is the answer through popular participation in national development and sense of belonging in national affairs and polity. As the institution of the state, the government is obliged to lead this struggle through dialogue, more consultations across the country and respect for the overwhelming opinions of the people on matters of national question within the frame of national ethics and values. The government should try to encourage civic education among the citizenry in promoting respect for national symbols and identities that give value to nationhood, such as respect for the constitution, national flag, national anthem, national traffic laws and the government institutions like the civil service, the head of state and his pictures among others not mentioned. This will promote national cohesion and love for patriotism and nationalistic feelings among the diverse people that make up the country and non- citizens resident in the country.

\section{REFERENCE LIST}

Akinboye et al, 2007, A Systematic Approach to International Relations, Concept Publications, Lagos. pp. $85-112$

Anifowoshe, e tal, 2005, Elements of Politics, Iroanusi Sam Publications, Lagos. Pp. 85-105. 6.Laski, 1952, $5^{\text {th }}$ ed; A Grammar of Politics, Allen and Unwin, London.

Appadorai, 1975, $11^{\text {th }}$ ed; The substance of Politics, Oxford University Press, London. Pp. 14-18.

Barker, 1928, The Study of Political Science and its Relation to Cognate Studies, Cambridge. UK.

BBC News Africa, 2014, Jan;15: 16:58GMT.

Economic Commission For Africa, 2011, National Strategy for Sustainable Development in Africa: A SixteenCountry Assessment, Addis Ababa, Ethiopia

Heywood, 2004, $3^{\text {rd }}$ ed; A Political Theory-An Introduction, Palgrave Basingstoke.

Heywood, 2007, $3^{\text {rd }}$ ed; Politics, Palgrave Foundations, Uk. pp. 110-126.

Holsti, K.J. 1983, $4^{\text {th }}$ ed; International Politics: A Framework For Analysis, Prentice-hall Int'l. Inc. pp. 29-92.

Garner, R. et al, $2^{\text {nd }}$ ed; Introduction to Politics, Oxford University Press, Uk.

Irobi, 2013, Ethnicity and nation-Building in Contemporary Africa: A Perspective for Non-killing Working

Papers, USA. ISSN 2077-141x (print); ISSN 2077-1428(Online).

Jagne, 2015, The Gambia-Taiwan Relations, 1970-2013, An unpublished Article, university of the Gambia, Brikama.

Laski, 1952, $5^{\text {th }}$ ed; A Grammar of Politics, Allen and Unwin, London.

Laski, 1967, A Grammar of Politics, Allen and Unwiin, London.

Maclver, 1966, The Modern State, OUP, London. 
National Development Strategy 2020: Active Society, Competitive Economy, Efficient State, Warsaw, September, 2012.

Nnaocha, 2012:1-2, Nation-State Building in The Colonial Gambia (1918-1970): A Historical Perspective,been a chapter in a book titlted 'Colonialism and the Transition to Modernty. In Africa, Edited by Joseph Mangut and Terhemba Wuam, Ibrahim Badamosi university, Niger State, Nigeria.

Omotosho, 2014, Ethnicity and Nation-Building in Nigeria, Race, Ethnicity and Place Conference Publication, Binghamton University, USA-web link@ http://rep-/abstracts/oyejide\%20felix\%20omotosho.pdf pp.34.

Omotosho, 2014, The Electoral Process in the Gambia: "A Giant Stride in the Makings of a Viable and Stable Political System, ICON, Canada, Global Journal Online Publication-web link; http://www.globaljournal.ca/englishpapers.html pp.4-16.

Omotosho, 2015, Nationhood and the Quest for national Development: The case of the Gambia Second Republic's Pragmatic Approach, The Gambia's Golden Jubilee Public Lecture Organized by the School of Arts and Sciences, University of the Gambia, Brikama Campus.

Omotosho, 2016, An Assessment of the Electoral and Democratization Process of the Gambia's First and Second Republics, 1965-2015: "A Comparative Analysis", Being a PhD Thesis submitted to the St. Clements University, West Indies in Partial Fulfillment for the Award of the PhD Certificate, 2016, chp.2.

Renan, E. 2011, "Que!st-cequ!une nation", conference faite en Sorbonne, le 11 Mars 1882, Accessed January 13,2011 .

Roskin, et al, 1994, Political Science: An Introduction, Prentice-Hall International, Inc. New Jersey, 07632.

The Voice Newspaper, 2015, Nationhood and the Quest for national Development: The case of the Gambia Second Republic's Pragmatic Approach, Vol.8.No.53 ISSN: 0796-130 (Authored by Omotosho, O. Felix).

United nations Development Assistance Framework (UNDAF), 2012-2016,, The Gambia, July,2011.

Weekend Observer, 2014, by Jawara Sanna, UTG lecturer (Omotosho, O. Felix) commends Gambia's Political system, ISSN 0796-0832 in www. Observer.gm, Vol.22, No.215, pp.6, $7^{\text {th }}-9^{\text {th }}$, November.

Web-Link Searches:

http://www.ruralpovertyportal.org/country/approaches/tags/gambia

http://dailynews.gmafrica/gambia/article/an-in-depth-analysis-of-development-registered-before-22july-andafter-asgambia-celebrates-48th-

http://www.statehouse.gm/vision2020/conclusion.htm

http://www.statehouse.gm/vision2020/conlusion.htm,

http://eeas.europa.eu/delegations/gambia/eu/gambiadevelpomentcooperation/index.en.htm

www.oxfordtextbooks.co.uk/orc/garner/ze. 